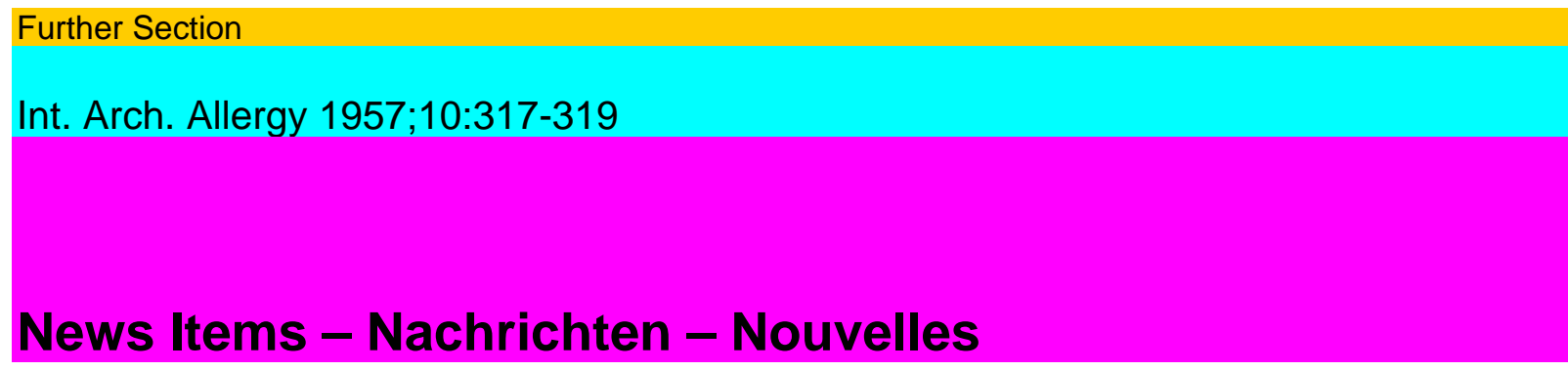

\title{
American College of Allergists
}

The Thirteenth Congress (1957) of the College in Chicago was attended by 296 members and 137 guests. The 1957 “Clemens von Pirquet Award” was presented to Mr. Donald Schqffer, University of Buffalo Medical School, the Women's Auxiliary “Béla Schick Prize” to Dr. Clyde K. Walker of Canfield, Ohio.

The College will hold its Fourteenth Congress in Atlantic City, New Jersey, at the Shelburne Hotel, April 20-25, 1958. Fellows as well as Associate Members who wish to present papers should send immediately an abstract of about 250 words or less to the Chairman of the Program Committee: Dr. Merle W. Moore, Medical Arts Building, Portland 5, Oregon.

American Medical Association

The 1958 AMA Session on Allergy will be held in June at the AMA Meeting in San Francisco, if it meets with the approval of the Council of the Scientific Assembly. Those who desire papers should communicate with the Secretary of the 1958 Session: Dr. R. Dale Dickson, 1008 Kansas Avenue, Topeka, Kansas.

The American Foundation for Allergic Diseases

The American Foundation for Allergic Diseases has announced a research and training program to encourage medical education in allergic diseases. Four classes of fellowship are offered: Predoctoral Fellowships-Two predoctoral fellowships of \$ 2500 have been awarded for 19561957 to Louis G. Hoffman and Jack Litwin, both working in microbiology at Johns Hopkins University and the University of Chicago, respectively.

Part-Time Fellowships-Forøí E. Brown, Harvard University, Boston, working in immunology has been awarded \$1500.

Postdoctoral Fellowships-Three such fellowships in research and clinical allergy have been established at Johns Hopkins University, Baltimore; Pennsylvania University, Philadelphia; and Washington University, St. Louis. They carry stipends of \$ 4500 for the first year, \$ 4750 for the second year, and laboratory and travel expense of $\$ 750$ for the two-year period. Funds were made available by a grant from Mr. John D. Rockefeller, Jr.

Summer or Quarterly Predoctoral Fellowships - Twenty quarterly or summer fellowships are available for students who have completed two years of medical school training. They are for a minimum of eight weeks and the stipend is \$ 500. A grant from the Gustavus and Louise Pfeiffer Foundation made these fellowships available.

New York Medical College Flower and Fifth Avenue Hospitals The «Division of Graduate Studies, Department of Graduate Pediatrics» announces a Post-Graduate Course in Pediatric Allergy under the direction of Bret Ratner, M. D., Professor of Clinical Pediatrics and Associate Professor of Immunology, November 6, 1957 - May 28, 1958, 30 Sessions (Wednesdays, 9 a.m. -4 p. m.). Fee. \$ 300.00 . 
The course consists of lecture-seminars, laboratory and clinical procedures, clinic work, and animal experimentation covering basic principles of diagnosis and treatment of allergy, and applied immunology in children.

318

News Items - Nachrichten - Nouvelles

Applicants must be certified in pediatrics or have the requirements for certification. A limited number of allergists practising with adults may also apply to:

Office of the Dean, New York Medical College, Fifth Avenue at 106th Street, New York 29, N.

Y.

International Association of Allergology

The Third International Congress of Allergology will be held in Paris, France, October 19-25, 1958. The scientific programme of the Congress will be composed of 1 . Symposia on "Asthma and Emphysema”, "Physio-Chemical Properties of Allergic Antibodies", "Recent Advances in Phases of Clinical Allergy", "Biochemical Aspects of Hypersensitivity”, "Auto-Immune Reactions". "Problems of Allergy Management and Socio-Economic Aspects of Allergy" and "Special Techniques in Clinical and Experimental Allergy (with demonstrations) " and 2. Short (ten-minute) papers on any phase of allergy, to be presented at sectional meetings.

Those who wish to present a short paper should mail title and abstract (100 to 200 words) to Dr. S. M. Feinberg, North Western University Medical School, 303 E. Chicago Avenue, Chicago 11, Illinois (from the U.S. and Canada), resp. to Dr. B. N. Halpern, 197 Blood. St. Germain, Paris Vile, France (from all other countries).

The Congress will be held in the New Medical School, a four-language interpreter phone system will be available. Information on local arrangements can be obtained from Dr. Halpern, general information from the Secretary-General of the LA. A., Dr. J. Q. Fossas, Paseo 313, Vedado, Havana, Cuba.

American Academy of Allergy

At the 13th Annual Meeting of the AAA, February 4-6, 1957, the following officers were elected:

W. B. Sherman (New York, N.Y.) President; M. Samter (Chicago, Ill.) President-Elect; M. B. Sulzberger (New York, N.Y.) Vice-President; F. C. Lowell (Boston, Mass.) Secretary; G. L. Blumstein (Philadelphia, Pa.) Treasurer and H. A. Howes (Detroit, Mich.) Historian.

The Journal of Allergy

Dr. W. B. Sherman resigned after seven years of service as Editor of the Journal of Allergy, and has been succeeded by Dr. F. C. Lowell, 56 E. Newton Street, Boston, Mass.

New York University College of Medicine

Alwin M. Pappenheimer, Jr., Ph. D., has been appointed professor and chairman of the Department of Microbiology. Dr. Pappenheimer has been on the staff of New York University College of Medicine since 1941 and previously held faculty positions with Harvard and with the University of Pennsylvania. He is Editor of the "Journal of Immunology" and "Bacteriological Reviews”.

Brazilian Allergy Society

The Society elected the following officers for 1957: President: F.J. da Silveira Lobo, Jr.; VicePresident: H. C. de Castro; First Secretary: P.Dias da Costa; Second Secretary: 0. Cavalcanti; Treasurer: A. JV. Sayao Lobato; Librarian: C. P. Lima.

Book Reviews - Buchbesprechungen - Livres nouveaux 319 Philadelphia Allergy Society 
The following officers were elected for 1957: President: E. E. Ehrlich; Vice-President: H. Petit; Secretary-Treasurer: E. A. Hildreth.

Uruguayan Allergy Society

The "Sociedad Uruguaya de Alergologia" was founded in October 1956. President: B. Varela

Fuentes; Vice-President: P. Recarte; Secretary: J. A. Moretti; Assistant Secretary: J. V. Megget. Venezuelan Allergy Society

The following officers were elected for 1957: President: M. Grainier; Vice-President: F. K. Vegas; Secretary: A. P. Lozano.

Book Reviews - Buchbesprechuogen - Livres Nouveaux

J. M. Converse and B. 0. Rogers (Chairmen): Proceedings of the Second Tissue Homotransplantation Conference. Ann. New York Acad. Sci. Vol. 64,

Art. 5, pages 735-1073, 1957.

On February 2-3, 1956, the Section of Biology of the New York Academy of

Sciences held its Second Conference on Tissue Homotransplantation. 28 papers

were presented by leading research workers. The main subjects of the Conference

were: 1 . Genetics, Phylogenetics and Acquired Tolerance; 2. Cellular Antibodies, Serum Antibodies, and Delayed Hypersensitivíty Phenomena; 3. Embryonal, Adult, and Tumor Tissue Homotransplants; and 4. Lymphocytes, Lymph Nodes and Homo transplantation. All the papers are expertly written and deal with basic immunological problems. The volume contains a vast amount of information, indispensable to immunologists. Paul Kallós, Helsingborg

E. H. Rubin: The Lung as a Mirror of Systemic Disease. Charles C Thomas, Publ., Springfield, Ill., 1956, 288 pages, 92 figures. \$ 12.50 .

This is a most interesting and extremely useful book. According to the author, the diseases of the lung "may be grouped into one of three categories. (1) Primary Diseases: These include developmental defects, new growths, traumatic injuries and similar conditions. The majority of the acute bacterial and viral pneumonias, pulmonary suppurations, primary pulmonary neoplasms and tuberculosis typify this group. (2) Secondary Diseases: These include pulmonary emboli, metastatic malignancies, and so called «terminal» pneumonias. (3) Concomitant Diseases: In these the respiratory tract is involved either initially or in the course of systemic diseases as an active, more-or-less co-equal participant.” The present mongraph is primarily concerned with the third group. About 80 systemic diseases, which are associated with pulmonary lesions, 